\title{
JOURNAL.RU
}

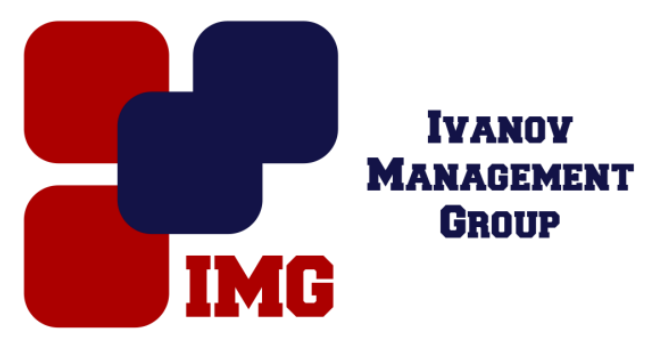

Владимиров И.А., Янбухтина Е.Н. Башкирский государственный аграрный университет Уфа, Россия

doi: $10.18411 / 1 \mathrm{j}-30-06-2017-18$

idsp 000001:1j-30-06-2017-18

\section{Муниципальное регулирование аграрного потребительского рынка}

\section{Аннотация}

В статье рассматривается использование аграрного рынка в процессе удовлетворения потребностей населения.

Ключевые слова: Муниципальное управление, муниципальное регулирование, аграрный рынок.

В данной статье рассмотрено регулирование аграрного рынка на муниципальном уровне. Важной составляющей муниципального управления, является регулирование потребительского рынка. От его состояния, уровня цен, ассортимента предлагаемых товаров и услуг зависит жизнедеятельность населения.

Муниципальное управление - это важная составляющая часть местного самоуправления, связанная с воздействием органов местного самоуправления на муниципальное образование и взаимодействие с входящими в его состав субъектами с целью повышения качества и уровня жизни населения муниципального образования.[1]

Внутри муниципального управления существует принцип разделения властей на исполнительную, законодательную и судебную. Исполнительная власть представлена главой муниципального образования, законодательная городским советом муниципального образования, и судебная - городским судом.

Муниципальное управление реализуется на определенной территории и связано с разными группами населения, живущими на этой территории. 
Муниципальное регулирование аграрного рынка является одной из важных составляющих муниципального управления. От состояния самого рынка, уровня цен на нем и ассортимента, предлагаемых товаров и услуг зависит повседневная жизнь населения.

Под муниципальным управлением потребительскими аграрными рынками следует понимать использование аграрного рынка в процессе удовлетворения потребностей населения муниципального образования.[1]

Основными задачами муниципального управления потребительскими аграрными рынками являются стабилизация и развитие производства, обеспечение безопасности в области продовольствия, улучшение обеспечения продовольствием населения муниципального образования, поддержание взаимоотношений и партнерства между сельским хозяйством и другими отраслями, взаимодействие товаропроизводителей на рынке.

Независимо от того, развивается сельскохозяйственное производство или нет, в каждой стране имеются аграрные рынки, так как через них производится обеспечение населения всем необходимым продовольствием и реализуется социально-экономическая политика государства.[3]

Определение аграрный рынок следует понимать как комплекс правовых отношений связанных с оформлением и осуществлением гражданско-правовых договоров касательно продукции сельского хозяйства.

Наиболее значимая черта аграрных отношений на данный момент- потеря рыночного существа. Аграрный рынок представляет собой сферу рыночных отношений. При этом главной его частью считается земельный рынок.

Работа аграрного рынка происходит зачастую в условиях повышенной нестабильности рыночной обстановки. Сельское хозяйство характеризуется годовым круговоротом. На протяжении года на рынок осуществляется сезонное поступлений товаров. Сезонные пики и падения дополняются погодными колебаниями. В связи с, вышеперечисленными обстоятельствами возникает повышенный риск предпринимательства. Агробизнесу характерны нестабильные цены и малоустойчивый доход. Поэтому чтобы преуспевать в конкуренции требуется немалый уровень профессионализма.

Аграрному рынку свойственны также жесткие ограничения на спрос сельскохозяйственной продукции. Так, например, вне зависимости от роста цены на хлеб, спрос на него остается прежним. Увеличение запасов зерна способствует уменьшению доходов крестьян. [2] 
Таким образом, под муниципальным управлением потребительскими аграрными рынками следует понимать использование аграрного рынка в процессе удовлетворения потребностей населения муниципального образования.

На сегодняшний день основными задачами муниципального управления потребительскими аграрными рынками являются стабилизация и развитие производства, обеспечение безопасности в области продовольствия, улучшение обеспечения продовольствием населения муниципалитета, поддержание партнерства между сельским хозяйством и прочимиотраслями, взаимоотношения товаропроизводителей на аграрном рынке.

\section{Литература}

1. Атаманчук Г.В. Государственное управление.[Текст] /Атаманчук Г.В.// - М.: ОАО «НПО «Экономика», 2010.

2. И.В. Скопина, Ю.О. Бакланова, А.О. Скопин.Инструментальное обеспечение управления развитием региональных потребительских рынков [Текст]/И.В. Скопина, Ю.О. Бакланова, А.О. Скопин//. - Н. Новгород, 2015.

3. О.И. Боткина, Э.Н. Кузьбожева, К.В. Павлова.Направления и реформы государственного регулирования рыночной экономик.[Текст]/ Под науч. ред. д-ра экон. наук, проф. О.И. Боткина, Э.Н. Кузьбожева, К.В. Павлова.// - Ижевск,2012. 